\title{
Similarity Analysis in Species Composition of the Aquatic Beetle Fauna among Some Indian Protected Areas in Respect to Satkosia and Baisipalli Wildlife Sanctuary, Odisha
}

\section{Sujit Kumar Ghosh', Udipta Chakraborti ${ }^{2 *}$, Puja Pati ${ }^{2}$, Bulganin Mitra'}

'Zoological Survey of India, Prani Vigyan Bhavan, M-Block, New Alipore, Kolkata,700053, West Bengal, India.

${ }^{2}$ Department of Zoology, University of Kalyani, Kalyani, Nadia, 741235, West Bengal, India.

Key words: Cluster analysis, Similarity \& Distance Index, Insect diversity

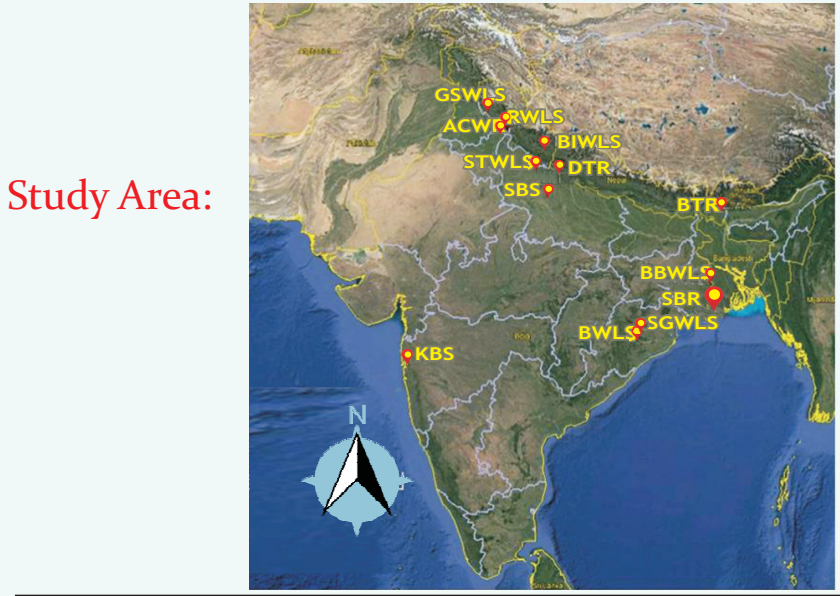

Introduction:

Generally, protected areas (PAs) are formed or declared through legal or other effective means to minimize the human activities and to achieve the long-term conservation of nature with associated ecosystem services and cultural values. The other approach of the establishment of protected area systems is to prevent the loss of biodiversity and to support the conservation policies. Unfortunately, insects (Terrestrial as well as aquatic) are always overlooked when bio-inventorisation of protected areas are concerned. Therefore, little is known about how protected areas represent the insect biodiversity with special reference to the aquatic beetle.

The group of water beetles is a potentially ideal indicator of the aquatic ecosystem and meets most of the criteria generally accepted in the selection of indicator taxa (Noss, 1990; Pearson, 1994). Their taxonomy is well known and well-studied in India, especially the family Dytiscidae (Ghosh \& Nilsson, 2012). Beetles occupy the

\section{Abstract}

Till date, aquatic beetle fauna among the thirteen Indian protected areas reported 86 species under 33 genera of 05 families of aquatic beetle species. Among the o5 families, Dytiscidae was included with the highest number of species whereas Haliplidae included the lowest. The highest numbers of species were found in Satkosia Gorge Wildlife Sanctuary (WLS) (19\% of total species) and minimum in Buxa Tiger Reserve, Bhibhutibhusan WLS and Binsar WLS ( $2 \%$ of total species).In respect of species composition, the maximum similarity was found in between Satkosia Gorge WLS and Baisipalli WLS (S\&D=0.64), and Binsar was having no similarity in view of species composition with the rest of the protected areas. Within the state, other than Odisha, the maximum similarity in species composition were found in between Buxa TR and Bhibhutibhusan WLS $(\mathrm{S} \& \mathrm{D}=0.14)$ in West Bengal. In Uttar Pradesh, Sandy Bird Sanctuary and Suraha Tal WLS are more similar in species composition ( $\mathrm{S} \& \mathrm{D}=0.47$ ) than others. Similarly, in Himachal Pradesh, Govind Sagar WLS and Renuka WLS are more similar in species composition $(\mathrm{S} \& \mathrm{D}=\mathbf{0 . 1 5})$. Whereas, no similarity were found in between Binsar Wildlife Sanctuary and Asan Wetland Conservation Reserve of Uttarakhand.

complete range of aquatic habitats, inhabiting virtually every kind of fresh and brackish water body (Ghosh et al., 2016). Furthermore, they show individual species specialization within habitats. They are present all the year round, sometimes in large numbers. Most species have ecological demands that are sufficiently limited to allow useful predictions to be made about changes in quality and land-use history or simply for characterizing the community and the habitat (Foster, 1987; 1996; Ribera \& Foster, 1992). They have already been used in some areas as biodiversity indicators for identifying priority areas of that region (Sánchez-Fernández et al., 2004).

Present work is an attempt to explore the aquatic beetle faunal diversity and to analyze the similarity in species composition of 11 protected areas from 05 states of India in respect to presently surveyed Satkosia Gorge WLS and Baisipalli WLS of Odisha. Apart from this, present communication also highlights the similarity in species composition of the protected areas within the states. 


\section{Methodology:}

Study area: Among the 13 protected areas, 03 from West Bengal: Sundarban Biosphere Reserve (SBR), Buxa Tiger Reserve (BTR) and Bhibhutibhushan Wildlife Sanctuary (BBWLS); 03 from Uttar Pradesh: Suraha Tal Wildlife Sanctuary (STWLS), Dudhwa Tiger Reserve (DTR) and Sandi Bird sanctuary(SBS); o2 each from Uttarkhand: Binsar Wildlife Sanctuary (BIWLS) and Asan Wetland Conservation Reserve (AWCR); Himachal Pradesh: Govind Sagar Wildlife Sanctuary (GSWLS) and Renuka Wildlife Sanctuary (RWLS) and Odisha: Satkosia Gorge Wildlife Sanctuary (SGWLS) and Baisipalli Wildlife Sanctuary (BWLS); o1 from Maharashtra: Karnala Bird Sanctuary (KBS) were studied (Table-1).

Among these 13 protected areas, 05 are Wildlife Sanctuaries, 02 bird sanctuaries, 02 Tiger Reserves, o1 Wetland conservation area and o1 Biosphere Reserve. The selection of all these protected areas were made on the basis of surveyed and studied by the authors of the present communication. The details of the protected areas are given in Table-1. All the species of true aquatic beetles present in the studied area and earlier reports were included in this communication except unidentified species. Data on species were obtained from the published literature and from fieldwork.

Table-1: Details of the protected areas (Pas)

\begin{tabular}{|c|c|}
\hline $\begin{array}{l}\text { Name, Year } \\
\text { Established }\end{array}$ & $\begin{array}{l}\text { Area Longitude/Latitude } \\
\left(\mathrm{Km}^{2}\right)\end{array}$ \\
\hline 6 & $\begin{array}{l}\text { Odisha } \quad 745 \cdot 52 \quad 84 \\
\text { Sp. No.: } 39 \text { Ref.: New Record }\end{array}$ \\
\hline BWLS, 1981 & $\begin{array}{l}\text { Odisha } 168.3584^{\circ} 45^{\prime} \mathrm{E} ; 20^{\circ} 29^{\prime} \mathrm{N} \\
\text { Sp. No.: } 34 \text { Ref.: New Record }\end{array}$ \\
\hline SBR, 1989 & $\begin{array}{l}\text { West Bengal } 426388^{\circ} 53^{\prime} \mathrm{E} ; 21^{\circ} 56^{\prime} \mathrm{N} \\
\text { Sp. No.: } 35 \text { Ref.: Mitra,2017 }\end{array}$ \\
\hline BTR, 1983 & $\begin{array}{l}\text { West Bengal } 757.989^{\circ} 34^{\prime} \mathrm{E} ; 26^{\circ} 39^{\prime} \mathrm{N} \\
\text { Sp. No.: } 4 \text { Ref.: Nandi et al., } 2004\end{array}$ \\
\hline BBWLS, 1985 & $\begin{array}{l}\text { West Bengal } 0.64 \quad 88^{\circ} 46^{\prime} \mathrm{E} ; 23^{\circ} 3^{\prime} \mathrm{N} \\
\text { Sp. No.: } 4 \text { Ref.: Ghosh, et al., } 2011\end{array}$ \\
\hline STWLS, 1991 & $\begin{array}{l}\text { Uttar Pradesh } 3432 \quad 84^{\circ} 10^{\prime} \mathrm{E} ; 25^{\circ} 50^{\prime} \mathrm{N} \\
\text { Sp. No.: } 13 \text { Ref.: Ghosh, et al., } 2010\end{array}$ \\
\hline DTR, & $\begin{array}{l}\text { Uttar Pradesh } 644 \quad 80^{\circ} 39^{\prime} \mathrm{E} ; 28^{\circ} 31^{\prime} \mathrm{N} \\
\text { Sp. No.: } 11 \text { Ref.: Ghosh \& Hedge, } 2013\end{array}$ \\
\hline SBS, & $\begin{array}{l}\text { Uttar Pradesh } \quad 3.085 \quad 79^{\circ} 58^{\prime} \mathrm{E} ; 27^{\circ} 18^{\prime} \mathrm{N} \\
\text { Sp. No.: } 18 \text { Ref.: Ghosh, } 2011\end{array}$ \\
\hline BIWLS, 1988 & $\begin{array}{l}\text { Uttarakhand } 47.0779^{\circ} 5^{\prime} \mathrm{E} ; 27^{\circ} 18^{\prime} \mathrm{N} \\
\text { Sp. No.: } 4 \text { Ref.: Ghosh et.al., } 2011\end{array}$ \\
\hline AWCR, 2005 & $\begin{array}{l}\text { Uttarakhand } 4.44477^{\circ} 39^{\prime} \mathrm{E} ; 30^{\circ} 26^{\prime} \mathrm{N} \\
\text { Sp. No.: } 9 \text { Ref.: Mukhopadhyay \& Ghosh, } 2003\end{array}$ \\
\hline GSWLS, 1962 & $\begin{array}{l}\text { Himachal Pradesh } 170 \quad 76^{\circ} 30^{\prime} \mathrm{E} ; 31^{\circ} 25^{\prime} \mathrm{N} \\
\text { Sp. No.: } 9 \text { Ref.: Ghosh, } 2015\end{array}$ \\
\hline RWLS, 2013 & $\begin{array}{l}\text { Himachal Pradesh } 4.00 \quad 77^{\circ} 27^{\prime} \mathrm{E} ; 30^{\circ} 36^{\prime} \mathrm{N} \\
\text { Sp. No.: } 21 \text { Ref.: Ghosh \& Hedge, } 2013\end{array}$ \\
\hline KBS, 1968 & $\begin{array}{l}\text { Maharashtra } \quad 4.48 \quad 73^{\circ} 7^{\prime} \mathrm{E} ; 18^{\circ} 53^{\prime} \mathrm{N} \\
\text { Sp. No.: } 9 \text { Ref.: Ghosh \& Hedge, } 2015\end{array}$ \\
\hline
\end{tabular}

Source: ENVIS Centre on Wildlife \& Protected Areas Hosted by Wildlife Institute of India, Dehradun (Updated- July 5, 2017)
Sponsored by Ministry of Environment, Forests \& Climate Change, Govt. of India

Abbreviation: Sundarban Biosphere Reserve (SBR), Buxa Tiger Reserve (BTR), Bhibhutibhushan Wildlife Sanctuary (BBWLS), Suraha Tal Wildlife Sanctuary (STWLS), Dudhwa Tiger Reserve (DTR), Sandi Bird sanctuary(SBS), Binsar Wildlife Sanctuary (BIWLS), Asan Wetland Conservation Reserve (AWCR), Govind Sagar Wildlife Sanctuary (GSWLS), Renuka Wildlife Sanctuary (RWLS), Satkosia Gorge Wildlife Sanctuary (SGWLS), Baisipalli Wildlife Sanctuary (BWLS), Karnala Bird Sanctuary (KBS).

Collection and Preservation: specimens were collected with the help of aquatic insect net from the bank of water bodies which were randomly selected in different studied areas. A line of approximately 10 meters was selected on each side of the selected water bodies and each side sampled for 3 times randomly. The collected species were preserved into $90 \%$ alcohol and taken to the laboratory of Zoological Survey of India, Kolkata for identif ication.

Ecological and statistical analysis: biodiversity Pro (version-2) software was used to analyze the rank of different protected areas regarding their similarity of species composition with Satkosia and Baisipalli respectively. Cluster analysis was done with the help of PAST software (Version-3.19) (Accessed on 1st April 2018), using a paired group algorithm (UPGMA) and Jaccard similarity measure. Jaccard Similarity measure was also used to determine the similarity and distance indices (S\&D index). The value of similarity and distance indices nearer to 1 indicates higher similarity whereas o indicates no similarity.

\section{Results:}

A total of 86 species under 33 genera of 05 families of aquatic beetles are reported from 13 selected protected areas. Of them, 39 species and 23 genera are reporting for the first time from Satkosia and 34 species and 20 genera from Baisipalli, (Table-2). The family Dytiscidae shared highest number of species (48 species under 16 genera), followed by Hydrophilidae (21 species under 12 genera), Gyrinidae (o9 species under 02 genera), Noteridae (o6 species under 02 genera) and Haliplidae (o2 species under o1genus) (Table-2).

Among the 86 species reported here, Regimbaertia attenuata of the family Hydrophilidae was found very common and distributed in o9 protected areas. Beside this, 02 species were reported from $08 \mathrm{PAs}$, 04 species from 07 PAs, o1 species from o6 PAs, 05 species from 05 PAs, 04 species from 04 PAs, 12 species from 03 PAs and 17 species from 02 PAs. But a majority of the species (40) were found only from a single protected area (Table-2).

Among the 13 studied protected areas, the highest number of species were found in SGWLS (19\%) and lowest from BIWLS (2\%) (Fig.-1). 
Table.2. List of Aquatic beetles recorded from the protected areas

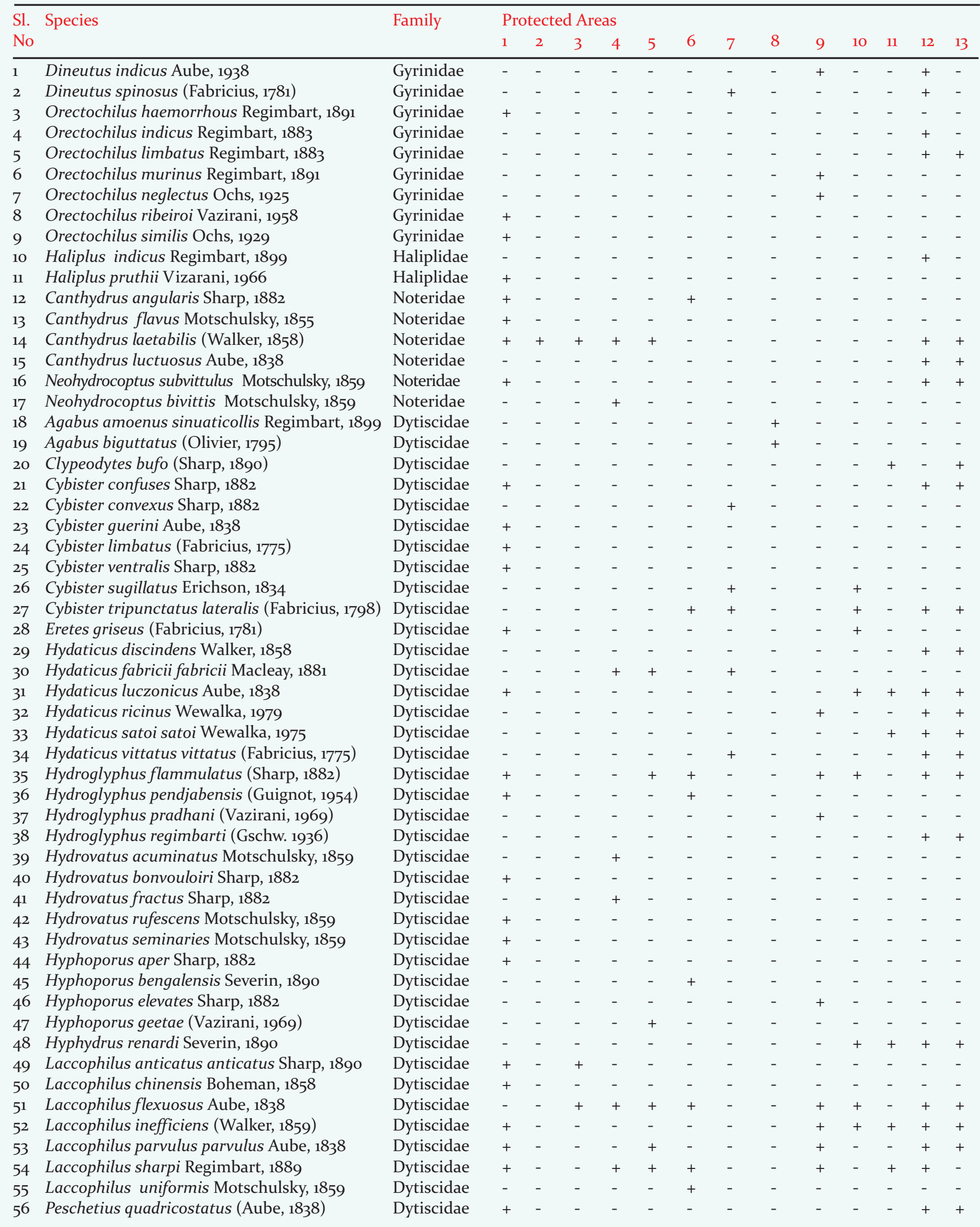




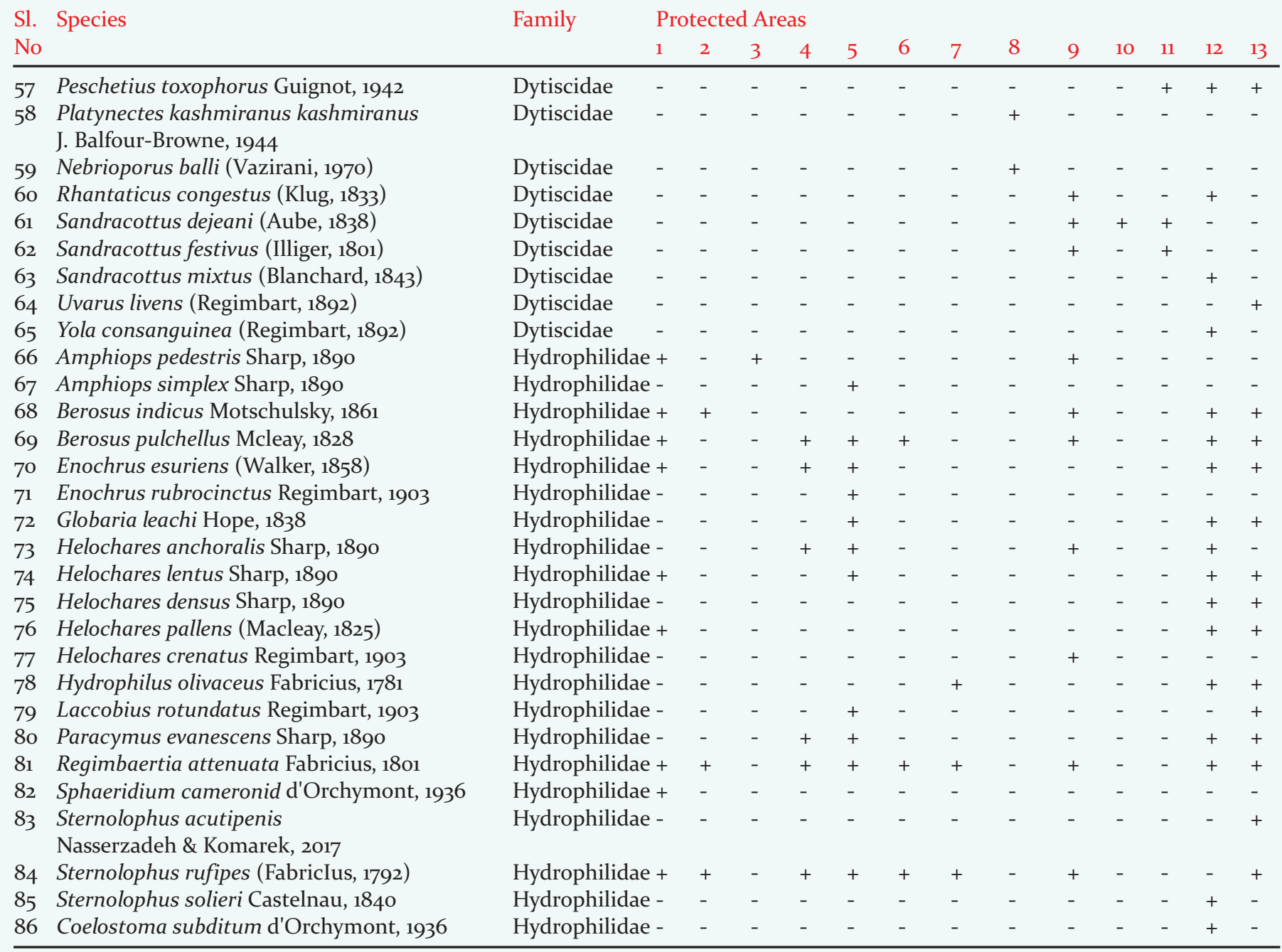

1: SBR, 2: BTR, 3: BBWLS, 4: STWLS, 5: SBS, 6: DTR, 7: AWCR, 8: BIWLS, 9: RWLS, 10: GSWLS, 11: KBS, 12: SGWLS, 13: BWLS

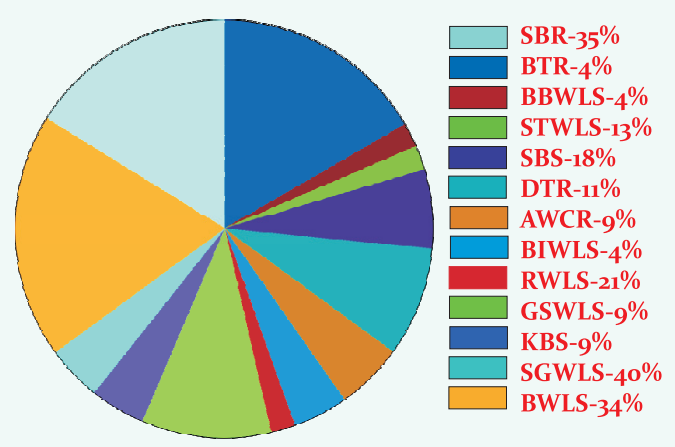

Figure-1: Species distribution in varios protected areas (\%-wise)

A similarity of species composition of different protected areas in respect to Satkosia WLS and Baisipalli WLS: it demonstrates the maximum and minimum similarity among these thirteen protected areas. As Binsar has no similarity in species composition with any protected areas, therefore Binsar is excluded from the analysis.

The cluster analysis among the 13 protected areas show that the maximum similarity in species composition of SGWLS is with BWLS and vice versa (S\&D index $=0.64$ ). The minimum similarity in species composition of SGWLS and BWLS are with BBWLS $(S \& D=0.04)$ and $(S \& D$ index $=0.05$ ) respectively (Fig.-2).

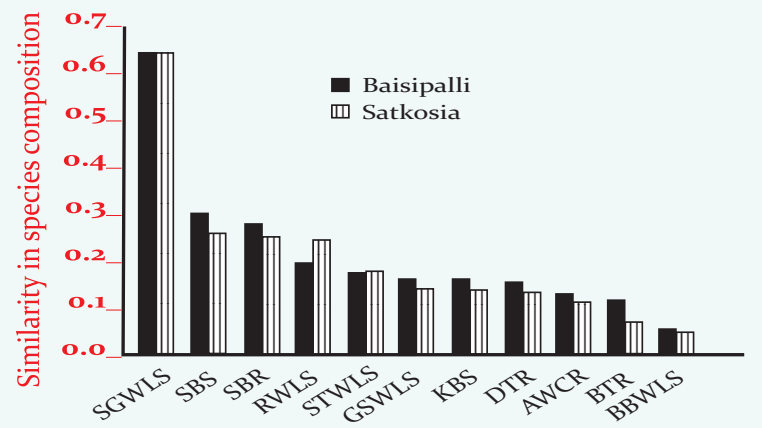

Figure-2: Similarity in species composition of Baisapalli and Satkosia with other protected areas

Similarity in species composition in different protected areas: SBR shown maximum similarity with BWLS (S\&D index $=0.27$ ) and minimum with AWCR (S\&D index=0.04). BTR showed more similarity with STWLS 


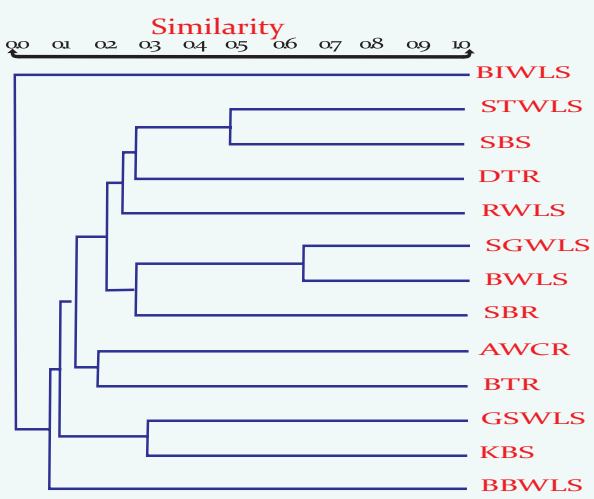

Figure-3: Cluster analysis of species composition among different PAs.

(S\&D index $=0.21$ ) minimum with KBS and GSWLS (S\&D index $=0$ ). BBWLS has shown maximum similarity ( $\& \& D$ index $=0.14$ ) with BTR and minimum with AWCR and KBS $(S \& D$ index $=0$ ). STWLS maximum with SBS (S\&D index $=0.47$ ) and minimum with GSWLS (S\&D index $=0.04$ ); SBS maximum with STWLS (S\&D index $=0.47$ ) and minimum with KBS (S\&D index $=0.03)$; DTR maximum with STWLS (S\&D index=0.26) and minimum with KBS (S\&D index=0.05); AWCR maximum with BTR (S\&D index $=0.18$ ) and minimum with BBWLS and KBS (S\&D index $=0$ ); RWLS maximum with SBS (S\&D index $=0.25$ ) and minimum with AWCR (S\&D index $=0.07$ ); GSWLS maximum with KBS (S\&D index=0.28) and minimum with BTR (S\&D index=o); KBS maximum with GSWLS (S\&D index $=0.28$ ) and minimum with BTR,BBWLS and AWCR (S\&D index=0) (Fig.-3).

Present paper also studied the similarity in species composition of the protected areas within the State. Among the six states, Maharashtra is excluded here for survey due to having only one PAs. Among the three PAs of West Bengal, the maximum similarity in species composition was observed in between BTR \& BBWLS (S\&D index $=0.14$ ). Similarly, SBS \& STWLS are more similar in species composition $(S \& D$ index $=0.47)$ in Uttar Pradesh. In between GSWLS \& RWLS of Himachal Pradesh, the similarity in species composition was (S\&D index $=0.15$ ). Whereas, no similarity has been found in between BIWLS \& AWCR of Uttarakhand. It is already stated that SGWLS \& BWLS of Odisha state is having the maximum similarity in species composition $(S \& D$ index $=0.64)($ Table-3).

Table-3: State wise Similarity in species composition of each PA

\begin{tabular}{lll}
\hline State & Protec ted Areas & S \& D index \\
\hline Odisha & SGWLS \& BWLS & 0.644 \\
Himachal Pradesh & GSWLS \& RWLS & 0.153 \\
Uttarakhand & BIWLS \& AWCR & No similarity \\
Uttar Pradesh & SBS \& DTR & 0.260 \\
& SBS \& STWLS & 0.47 \\
West Bengal & DTR \& STWLS & $\mathbf{0 . 2 6 3}$ \\
& SBR \& BTR & 0.114 \\
& BTR \& BBWLS & 0.142 \\
& BBWLS \& SBR & 0.083
\end{tabular}

\section{Discussion:}

This work also highlights the commonness of the species among the 13 protected areas. Among the 86 species found in the referred PAs, 40 species were found to distribute only in a single protected area. Regimbaertia attenuata of the family Hydrophilidae is found in maximum number of PAs (o9 protected areas). The maximum numbers of species (15 species) were reported only from Sundarban Biosphere Reserve. Therefore, it is high time to provide a conservation priority to SBR for its unique species assemblage.

Hydroglyphus flammulatus, Hydroglyphus regimbarti, Laccophilus parvulus parvulus ,Laccophilus sharpi, Canthydrus laetabilis, Canthydrus luctuosus, Neohydrocoptus subvittulus, Amphiops pedestris, Berosus indicus , Berosus pulchellus, Enochrus esuriens, Helochares anchoralis, Helochares pallens, Regimbaertia attenuata, Sphaeridium cameroni, Sternolophus rufipes of this study were reported earlier by Ghosh et al. (2016) from the brackish water of Chilika. Presence of these beetles from high altitude [Renuka (RWLS)and Govind sagar (GSWLS)] to low altitude (Sundarban Biosphere Reserve) are proving their ability to adapt in different climatic zones and invarious salinity range.

This study also reveals that it is not obvious, the species composition would be similar in between adjacent protected areas or dissimilar in between distant protected areas. In this study, it has been found that SBR is having maximum similarity with BWLS of Odisha (S\&D index=0.27) than closer one (BBWLS \& BTR in West Bengal).

This study can be treated as a pilot project to understand the similarity in species composition among the protected areas of different climatic zones in India. We hope, this baseline information will help to monitor the aquatic beetle diversity for conservational aspects and certainly prevent the loss of biodiversity.

\section{Acknowledgements:}

Authors are grateful to Dr. Kailash Chandra, Director of Zoological Survey of India, for providing necessary facilities and encouragement in preparation of the manuscript. First author thankful to Shri K.C. Gopi, Add. Director \& Divisional-in-Charge for his valuable advice and Dr. O.P. Srivastava, O/C Coleoptera section for his moral support.

\section{References:}

Foster, G.N. (1987): The use of Coleoptera records in assessing the conservation status of wetlands. In Luff M, ed: The Use of Invertebrate Community Data in Environmental Assessment. pp. 8-18. Pub. by: University of Newcastle: Newcastle upon Tyne.

Foster, G.N. (1996): Beetles as indicators of wetland conservation quality. In: Eyre MD,ed.: Environmental Monitoring, Surveillance and Conservation Using Invertebrates. pp. 33-35. Pub. by:: EMS Publications: Newcastle upon Tyne.

Ghosh, S.K. \& Nilsson, A.N. (2012): Catalogue of the diving beetles 
of India and adjacent countries (Coleoptera: Dytiscidae). Skörvnöpparn, Umeå, Supp., 3: 1-77

Ghosh, S.K., Das, P., \& Mitra, B. (2016): Studies on the fresh water aquatic beetle fauna (Coleoptera: Insecta) of Chilika lake and its adjoining areas and their colonization in brackish water. Int. J. Fauna Biol. Stud.,. 3(6):19-24.

Ghosh, S.K., Ghosh, P. \& Mitra, B. (2010): On a Collection of Aquatic Beetles from Suraha Tal Wild Life Sanctuary, Ballia, U.P. Bionotes, $12(3)$ : 95 .

Ghosh, S., Ghosh, P. \& Mitra, B. (2011): On a collection of aquatic beetles from Bibhutibhushan Wildlife Sanctuary, West Bengal. Bugs RAll, Newslett., 17:9-10

Ghosh, S.K., Ghosh, P. \& Mitra, B. (2011): A preliminary report on the predaceous diving beetles (Dytiscidae: Coleoptera) of Binsar wildlife Sanctuary, Uttarakhand. Bug RAll., 17:19-20.

Ghosh, S.K. (2011): On a Collection of Aquatic Beetles (Order Coleoptera: Family Noteridae, Dytiscidae and Hydrophilidae) from Sandi Bird Sanctuary, Uttar Pradesh, India. Bionotes, 13(4):161.

Ghosh, S.K. \& Mitra, B. (2014): Further records of aquatic beetles from Sunderban Biosphere Reserve, West Bengal. Bionotes, 16(2):67-68.

Ghosh, S.K., Chakraborti, U., Roy, S., Biswas, O., Shah, S.K. \& Mitra, B.(2015): New Records of Some Aquatic Beetles from Sunderban, West Bengal. Bionotes, 17(1):25.

Ghosh, S.K., Chakraborti, U., Biswas, O., Roy, S., Shah, S.K. \& Mitra, B. (2015): On a Collection of Aquatic Beetles from Sagar Island, West Bengal. Bionotes, 17 (4):107.

Ghosh, S.K. \& Hegde, V.D. (2013): On a Collection of Aquatic Beetles from Dudhwa Tiger Reserve, Uttar Pradesh, India. Zoo's Print, 28(9): 21-22.

Ghosh, S.K. \& Hegde, V.D. (2013): On a Collection of Aquatic Beetles of Renuka Wildlife Sanctuary, Himachal Pradesh, India (Order Coleoptera: Gyrinidae, Dytiscidae and Hydrophilidae). Rec. zool. Surv. India, 113 (2);:61-67.

Ghosh SK \& Hegde VD.(2015): Diving Beetles of Karnala Bird Sanctuary, Maharashtra, India (Coleoptera: Dytiscidae). Rec. zool. Surv. India, $115(1) ;: 73-75$.
Ghosh, S.K. (2015): Diving beetles of Govind Sagar Wildlife Sanctary, Himachal Pradesh (Coleoptera : Adephaga: Dytiscidae). Rec.zool.Surv. India, 115(1):77-80.

Hammer, Ø., Harper, D.A.T. \& Ryan, P.D. (2001): Past: Paleontological statistics software package for education and data analysis. Palaeontologia Electronica, 4(1): 1-9.

McAleece, N., Gage, J.D.G., Lambshead, P.J.D. \& Paterson, G.L.J. (1997) BioDiversity Professional statistics analysis software. Jt. dev. by: Scottish Association for Marine Science and Natural History Museum London.

Mitra B. (2017): Insect faunal diversity and their ecosystem services in Sundarban Biosphere Reserve. pp 137-173. In: Chandra, Alfred, Mitra \& Roy Chowdhury eds.-Fauna of Sundarban Biosphere Reserve. Pub. by: Zoological Survey of India, India.

Mukhopadhyay, P. \& Ghosh, S.K. (2003): Insect: Coleoptera (Aquatic), . Zool. Surv. India, Fauna of Asan Wetland (Derhadun vally: Uttarakhand). Wetland Ecosys. Ser., 5(1-4): 15-17.

Nandi, N.C., Mukhopadhyay, P., Ghosh, S.K. \& Das, S.K.(2004): Notes on Aquatic Entomfauna of Narathaly Lake of Buxa Tiger Reserve, West Bengal. Rec. zool. Surv. India,102 (12):53-56.

Noss, R.F. (1990): Indicators for monitoring biodiversity: a hierarchical approach. Conserv. Biol., 4(4):355-364.

Pearson, D.L. (1994): Selecting indicator taxa for the quantitative assessment of biodiversity. Philos. Trans. R. Soc. Lond. B. Biol. Sci., 29;345(1311):75-79.

Ribera, I. \& Foster, G.N (1992): Uso de Coleópteros acuáticos como indicadores biológicos (Coleoptera). Elytron. 6: 61-75

Sánchez-Fernández, D., Abellán, P., Velasco, J. \& Millán, A. (2004):. Selecting areas to protect the biodiversity of aquatic ecosystems in a semiarid Mediterranean region using water beetles. Aquatic Conserv: Mar. Freshw. Ecosyst., 14: 465-479. 